\title{
Kemampuan Guru Fisika dalam Menerapkan Model-Model Pembelajaran pada Kurikulum 2013 serta Kendala-Kendala yang Dihadapi
}

\author{
Rizky Febriyani Putri ${ }^{1}$ *, J. Jumadi ${ }^{1}$ \\ ${ }^{1}$ Program Studi Pendidikan Fisika, Program Pascasarjana, Universitas Negeri Yogyakarta. \\ Jalan Colombo No. 1, Karangmalang, Yogyakarta, 55281, Indonesia \\ * Corresponding Author. Email: febyonly@gmail.com \\ Received: 21 April 2016; Revised: 30 May 2017; Accepted: 25 October 2017
}

\begin{abstract}
Abstrak
Penelitian ini bertujuan untuk: (1) mendeskripsikan kemampuan guru Fisika SMA Negeri di Kabupaten Sleman dalam merencanakan dan melaksanakan pembelajaran dengan model-model yang ditentukan pada Kurikulum 2013, dan (2) mengidentifikasi kendala-kendala yang dihadapi guru Fisika dalam menerapkan model-model pembelajaran yang ditentukan pada Kurikulum2013. Penelitian ini merupakan penelitian survei dengan menggunakan pendekatan deskriptif kuantitatif. Hasil penelitian ini menunjukkan bahwa: (1) kemampuan guru merencanakan dan melaksanakan pembelajaran masuk kategori baik, dan (2) kendala yang dihadapi guru yaitu pada perubahan format RPP, alokasi waktu untuk melaksanakan model pembelajaran pada Kurikulum 2013, dan pelaksanaan penilaian kompetensi sikap.
\end{abstract}

Kata Kunci: kemampuan guru, perencanaan pembelajaran, pelaksanaan pembelajaran, Kurikulum 2013

\section{Senior High School Physics Teacher's Ability to Apply The Learning Models of 2013 Curriculum and the Obstacles Faced}

\begin{abstract}
This study aimed to: (1) describe the senior high school Physics teacher's ability in Sleman to plan and implement the learning models of the 2013 Curriculum, and (2) identify the obstacles faced by Physics teachers in applying learning models that have been specified in the 2013 curriculum. This research was a survey using quantitative descriptive approach. The results of this research indicate that: (1) the teacher's ability to plan and to implement learning models is categorized as good, and (2) the constraints that teachers face are the change in the format of the lesson plan, the allocation of time to implement learning models in the 2013 curriculum, and implementation of the attitude assessment
\end{abstract}

Keywords: the teacher's ability, instructional planning, implementation of learning, 2013 curriculum

How to Cite: Putri, R., \& Jumadi, J. (2017). Kemampuan guru fisika dalam menerapkan model-model pembelajaran pada Kurikulum 2013 serta kendala-kendala yang dihadapi. Jurnal Inovasi Pendidikan IPA, 3(2), 201-211. doi:http://dx.doi.org/10.21831/jipi.v3i2.8636

Permalink/DOI: http://dx.doi.org/10.21831/jipi.v3i2.8636 


\section{PENDAHULUAN}

Pemerintah Republik Indonesia melalui Kementerian Pendidikan dan Kebudayaan mengadakan perbaikan dan pembaharuan sistem pendidikan di Indonesia, yaitu dalam bentuk pembaharuan kurikulum, penataan guru, peningkatan manajemen pendidikan, serta pembangunan sarana dan prasarana pendidikan. Dengan pembaharuan ini diharapkan dapat meningkatkan mutu pendidikan di Indonesia. Peningkatan mutu pendidikan akan tercapai apabila kegiatan belajar mengajar di kelas efektif sehingga peran guru teramat penting dalam mencapai peningkatan mutu pendidikan nasional, perhatian dan analisis pun perlu diarahkan kepada guru ini dalam melaksanakan tugas pembelajarannya.

Komponen pendidikan yang sangat menentukan terselenggaranya proses pendidikan dengan baik adalah guru. Sejalan dengan pendapat Nadeem et al. (2011, p. 218) bahwa dalam semua sistem pendidikan, kinerja guru merupakan salah satu faktor utama penentu efektivitas sekolah dan hasil belajar. Tidak banyak guru yang mampu menjalankan peran dan fungsinya secara memadai. Permasalahan yang dihadapi datang dari fasilitas, kultur sosial sekolah setempat, atau sistem pendidikan. Guru dituntut mampu mengelola pengajaran yaitu pada menentukan strategi dan perencanaan serta diakhiri dengan penilaian. Uno (2007, p. 15) menyatakan guru adalah orang yang memiliki kemampuan merancang program pembelajaran serta mampu menata dan mengelola kelas agar peserta didik dapat belajar. Menurut Suparlan (2008, p. 12), guru dapat diartikan sebagai orang yang tugasnya terkait dengan upaya mencerdaskan kehidupan bangsa dalam semua aspeknya, baik spiritual dan emosional, intelektual, fisikal, maupun aspek lainnya. Dari pengertian di atas dapat disimpulkan bahwa guru adalah suatu profesi yang secara legal formal maupun tidak formal yang bertugas mencerdaskan kehidupan bangsa dengan kemampuannya merancang program pembelajaran yang digunakan untuk melaksanakan tugas utamanya dalam mendidik, mengajar, membimbing dan mengevaluasi peserta didik baik di dalam kelas maupun di luar kelas.

Guru merupakan pihak pertama yang paling bertanggungjawab dalam pentransferan ilmu pengetahuan kepada peserta didik. Rusman (2010, p. 58) berpendapat bahwa guru merupakan faktor penentu yang sangat dominan dalam pendidikan pada umumnya, karena guru memegang peranan dalam proses pembelajaran, di mana proses pembelajaran merupakan inti dari proses pendidikan secara keseluruhan. Hasriani \& Arty (2015, p. 116) juga berpendapat bahwa keberhasilan pendidikan dalam mencapai tujuan sangat ditentukan oleh peran pendidik.

Dalam teori education production function, guru, kurikulum, sarana dan prasarana pendidikan termasuk dalam kategori sebagai instrumental input. Sementara itu, peserta didik termasuk sebagai raw input yang akan diproses dengan menggunakan instrumental input tersebut. Implementasi teori education production function di Indonesia dianggap terlalu mementingkan instrumental input, dan kurang memfokuskan masalah proses pembelajaran di dalam kelas. Kenyataan menunjukkan bahwa hasil pendidikan tidak seperti yang diharapkan. Mutu pendidikan masih memprihatinkan, karena terlalu berorientasi kepada instrumental input, dan tidak atau kurang memerhatikan proses pembelajaran yang dirancang guru di dalam kelas. Proses pembelajaran di dalam kelas merupakan black box (kotak hitam) yang seharusnya lebih memperoleh perhatian secara serius dari guru, tanpa harus mengabaikan masukan instrumentalnya (Suparlan, 2008, p. 34).

Salah satu faktor yang mempengaruhi terjadinya tujuan pembelajaran dan pendidikan di sekolah yaitu kompetensi guru. Adapun macam-macam kompetensi yang harus dimiliki oleh tenaga guru antara lain: kompetensi pedagogik, kompetensi kepribadian, kompetensi sosial, dan kompetensi profesional. Kompetensi pedagogik meliputi pemahaman guru terhadap peserta didik, perancangan dan pelaksanaan pembelajaran, evaluasi hasil belajar, dan pengembangan peserta didik untuk mengaktualisasikan berbagai potensi yang dimilikinya (Kurniasih \& Sani, 2014, p. 24).

Selain kompetensi, guru juga mengerahkan berbagai keterampilan dasar mengajar. Menurut Wiyani (2013, p. 33) ada tujuh keterampilan dasar mengajar yang harus dikuasai guru, yaitu: (1) kemampuan bertanya; (2) keterampilan memberi penguatan; (3) keterampilan mengadakan variasi; (4) keterampilan menjelaskan; (5) keterampilan membuka dan menutup pelajaran; (6) keterampilan membimbing diskusi; dan (7) keterampilan mengelola kelas. Keterampilan dasar mengajar yang telah dijabarkan merupakan bekal guru sebagai pemimpin pembelajaran di kelas. Dalam konteks kelas, guru sebagai seorang leader berperan sebagai pengelola atau manajer pembelajaran. Ada 


\section{Jurnal Inovasi Pendidikan IPA, 3 (2), 2017 - 203}

Rizky Febriyani Putri, J. Jumadi

empat komponen keterampilan manajemen kelas, yaitu: (1) keterampilan mengadakan pendekatan secara pribadi; (2) keterampilan mengorganisasi; (3) keterampilan membimbing dan memudahkan belajar; dan (4) keterampilan merencanakan dan melaksanakan kegiatan belajar mengajar. Dalam mengelola proses belajar mengajar, kemampuan guru sangat berkaitan erat dengan tiga fungsi manajerial yaitu perencanaan, pelaksanaan, dan evaluasi.

Dari beberapa kompetensi, keterampilan, dan kemampuan guru yang telah disebutkan di atas, kemampuan guru dalam merencanakan pembelajaran adalah kemampuan guru dalam merancang pembelajaran dengan memahami landasan pendidikan. Rencana pembelajaran yang dirancang mencakup: (a) identitas sekolah/ madrasah, mata pelajaran, kelas/semester, dan alokasi waktu; (b) kompetensi inti, kompetensi dasar, indikator pencapaian kompetensi; (c) materi pembelajaran; (d) kegiatan pembelajaran; (e) penilaian; dan (f) media/alat, bahan, dan sumber belajar.

Kemampuan guru dalam melaksanakan pembelajaran adalah kemampuan guru dalam menata latar (setting) pembelajaran secara keseluruhan proses belajar dan pembentukan kompetensi yang direncanakan, mencakup: (a) mengelola ruang dan fasilitas pembelajaran; (b) melaksanakan kegiatan pembelajaran yang meliputi kegiatan pendahuluan, kegiatan inti, dan kegiatan penutup; (c) mengelola interaksi kelas; (d) mendemonstrasikan kemampuan khusus dalam pembelajaran mata pelajaran; dan (e) melaksanakan penilaian dalam pembelajaran saintifik.

Alat untuk mencapai tujuan pendidikan adalah kurikulum. Seperti kita ketahui, sistem pendidikan Indonesia telah menetapkan Kurikulum 2013 pada bulan Juli 2013 lalu, sementara itu, Peraturan Menteri Nomor 159 Tahun 2014 tentang Evaluasi Kurikulum 2013 setelah tiga bulan Kurikulum 2013 dilaksanakan di seluruh Indonesia, Mendikbud RI memutuskan menghentikan pelaksanaan Kurikulum 2013 di sekolah-sekolah yang baru menerapkan satu semester dan tetap menerapkan Kurikulum 2013 di sekolah-sekolah yang telah menerapkan Kurikulum 2013 selama tiga semester.

Pelaksanaan Kurikulum 2013 merupakan sesuatu yang baru bagi guru, tak terkecuali guru Fisika. Seperti yang dinyatakan Hussain, Dogar, Azeem, \& Shakoor $(2011$, p. 264), guru harus memiliki pengetahuan tentang kurikulum dan memahami proses dimana kurikulum dapat dikembangkan. Munculnya Kurikulum 2013, memerlukan penyesuaian guru dalam mengemas pembelajaran sesuai dengan yang tertuang dalam Kurikulum 2013. Sejumlah persiapan yang seharusnya dilakukan guru, yaitu menyusun rencana pelaksanaan pembelajaran, sumber belajar dan instrumen penilaian dengan strategi pengimplementasian yang tepat. Hal tersebut sejalan dengan pendapat Mundry \& LoucksHorsley $(1999$, p. 5) yang menyatakan bahwa "if the decision is to engage in curriculum development or adaptation, make sure that teachers have the content knowledge needed to translate reform ideas into specific and coherent curriculum, and that they have sample time to develop, test, and refine the curriculum materials." Jadi, berdasarkan pendapat tersebut bila guru diberi kesempatan untuk mengembangkan atau mengadopsi kurikulum, maka pemerintah atau tim pengembang kurikulum harus memastikan bahwa guru memiliki pengetahuan yang dibutuhkan untuk menerjemahkan ide ke dalam bentuk kurikulum yang spesifik dan koheren, serta diberi kesempatan untuk mengembangkan, mengetes dan memperbaiki materi kurikulum. Oleh karena itu, guru dituntut untuk memiliki kemampuan baik secara konseptual maupun praktikal untuk melaksanakan langkah-langkah dalam pengembangan kurikulum.

Menurut Cullen (2011, p. 217), "the curriculum emphases must be in concert with local needs and reflective of students' attitudes and aspiration". Kurikulum harus melibatkan guru dan masyarakat, penekanan kurikulum harus sesuai dengan kebutuhan lokal serta mencerminkan sikap dan aspirasi peserta didik. Karena pentingnya maka setiap kurikulum selalu dievaluasi untuk kemudian disesuaikan dengan perkembangan ilmu pengetahuan dan kemajuan teknologi.

Setiap perubahan kurikulum tentu membawa karakteristik tersendiri. Demikian juga pada model pembelajaran yang diterapkan pada kurikulum baru tersebut. Salah satu hal pokok dalam penerapan Kurikulum 2013 adalah bagaimana guru mampu menerapkan pendekatan saintifik yang berpusat pada peserta didik serta menekankan pada pembelajaran peserta didik aktif, yaitu dengan diterapkannya model pembelajaran discovery learning, problem based learning, dan project based learning

Dalam kegiatan pembelajaran sering terjadi kendala yang dapat menghambat suksesnya proses belajar. Rohani (2004, p. 68) menam- 
bahkan, yang termasuk komponen belajar mengajar antara lain tujuan instruksional yang hendak dicapai, materi pelajaran, metode mengajar, alat peraga pengajaran dan evaluasi-evaluasi sebagai alat ukur tercapai tidaknya tujuan. Perubahan dan pengembangan kurikulum menjadi salah satu kendala yang dirasakan guru dalam kegiatan belajar mengajar terutama pada aspek perencanaan dan pelaksanaan. Model pembelajaran mempunyai andil yang cukup besar dalam kegiatan belajar mengajar. Kemampuan yang diharapkan dapat dimiliki peserta didik akan ditentukan oleh kerelevansian penggunaan suatu model pembelajaran yang sesuai dengan tujuan. Hal ini berarti tujuan pembelajaran akan dicapai dengan penggunaan model yang tepat.

Kendala yang dihadapi terutama berkaitan dengan proses pemahaman kurikulum itu sendiri. Pada Kurikulum 2013, model pembelajaran yang diutamakan adalah model Inquiry Based Learning, model Discovery Learning, model Project Based Learning, dan model Problem Based Learning. Model pembelajaran yang telah disebutkan adalah model pembelajaran yang banyak melibatkan peserta didik dalam kegiatan belajar mengajar. Dengan adanya perubahan dan pengembangan kurikulum, memerlukan penyesuaian guru dalam mengemas pembelajaran sesuai yang tertuang dalam Kurikulum 2013, guru harus mampu menerapkan Kurikulum 2013 secara tepat dalam perencanaan, pelaksanaan, dan penilaian agar mampu meningkatkan kompetensi peserta didik.

Kendala yang dimaksud dalam penelitian ini adalah kendala yang dialami oleh guru Fisika dalam menerapkan model-model pembelajaran yang ditentukan pada Kurikulum 2013. Kendala-kendala yang dialami guru dilihat dari adanya perubahan dan pengembangan Kurikulum 2013, yaitu pada: (1) format RPP; (2) model pembelajaran yang ditentukan; (3) pendekatan pembelajaran; dan (4) teknik penilaian.

Hasil penelitian yang dilakukan oleh Rezeki \& Setiawan (2015) yang berjudul "Analisis Kemampuan Pedagogik Guru Sekolah Dasar terhadap Kurikulum 2013 di Kecamatan Medan Area" salah satu variabelnya tentang Kurikulum 2013. Hasil ini menyimpulkan bahwa (1) kemampuan kognitif guru SD di Kecamatan Medan Area tentang kemampuan pedagogis guru dalam pelaksanaan Kurikulum 2013 dari keseluruhan indikator diperoleh nilai ratarata 2,70 baik. Hasil yang diperoleh oleh kemampuan guru untuk indikator kemampuan untuk memahami peserta didik, mengembang- kan kurikulum atau silabus, belajar untuk merancang, melaksanakan dan belajar dialogis mendidik, dan mengembangkan peserta didik untuk mengaktualisasikan berbagai potensi yang dimiliki adalah kategori baik. Dalam indikator kemampuan untuk mengevaluasi hasil belajar adalah kategori cukup baik. Sedangkan indikator kemampuan untuk memanfaatkan teknologi instruksional diklasifikasikan kategori kurang baik; (2) Guru Sekolah Dasar di Kecamatan Medan Area, dalam praktek rata-rata memiliki kemampuan pedagogik yang relatif baik untuk menerapkan kurikulum pada tahun 2013. Hasil yang diperoleh pada indikator kemampuan pedagogik guru untuk merencanakan dan melaksanakan program kegiatan belajar adalah kategori baik. Sementara indikator untuk mengevaluasi kemampuan belajar adalah kategori cukup baik.

Berdasarkan latar belakang yang telah dikemukakan, tujuan dari penelitian ini adalah (1) mendeskripsikan kemampuan guru Fisika SMA Negeri di Kabupaten Sleman dalam merencanakan dan melaksanakan pembelajaran dengan model-model pembelajaran yang ditentukan Kurikulum 2013, dan (2) mengidentifikasi kendala-kendala yang dihadapi guru Fisika dalam menerapkan model-model pembelajaran yang ditentukan pada Kurikulum 2013.

\section{METODE}

Penelitian ini merupakan penelitian survei dengan menggunakan pendekatan deskriptif kuantitatif. Penelitian ini tidak memberikan perlakuan apapun terhadap subjek penelitian, tetapi hanya melakukan observasi dokumen perencanaan guru dan ketika guru melaksanakan pembelajaran di kelas.

Penelitian dilaksanakan di SMA Negeri di Kabupaten Sleman pada Tahun Ajaran 2015/ 2016 semester gasal dengan pertimbangan bahwa sekolah-sekolah tersebut tetap melanjutkan Kurikulum 2013, yaitu: (1) SMA Negeri 1 Godean; (2) SMA Negeri 1 Kalasan; (3) SMA Negeri 1 Pakem; (4) SMA Negeri 1 Prambanan; (5) SMA Negeri 1 Seyegan; dan (6) SMA Negeri 1 Sleman. Penelitian ini dilaksanakan pada bulan Agustus 2015 sampai dengan bulan Oktober 2015.

Populasi dalam penelitian ini adalah guru Fisika di seluruh SMA Negeri di wilayah Kabupaten Sleman yang menerapkan Kurikulum 2013 yang berjumlah 18 orang, dimana guru sertifikasi berjumlah 16 orang dan nonsertifikasi berjumlah 2 orang. Pemilihan sampel dilakukan 
dengan cara proportional stratified random sampling, yaitu pengambilan sampel dari anggota populasi secara acak dan berstrata secara proporsional dengan anggota populasi yang heterogen. Diperoleh sampel penelitian yaitu 10 guru sertifikasi dan 1 guru nonsertifikasi.

Pelaksanaan penelitian ini dilakukan dalam beberapa kegiatan, yaitu: (1) prasurvei ke sekolah untuk mengetahui jumlah guru yang diteliti; (2) penyusunan instrumen penelitian; (3) pengambilan data penelitian; (4) data yang diperoleh dikumpulkan, disusun, dianalisis, dan diinterpretasikan; dan (5) penyusunan laporan penelitian.

\section{Data, Instrumen, dan Teknik Pengumpulan Data}

Data dalam penelitian ini adalah data observasi kemampuan guru merencanakan dan melaksanakan pembelajaran, serta kendalakendala yang dihadapi. Instrumen yang digunakan adalah lembar observasi kemampuan guru merencanakan pembelajaran dan lembar observasi kemampuan guru melaksanakan pembelajaran. Teknik pengumpulan data menggunakan teknik observasi, dokumentasi dan wawancara tidak berstruktur.

Validitas dan Reliabilitas Instrumen

Dari segi validitas isi, instrumen lembar observasi dan lembar angket layak digunakan menurut ahli. Dari segi validitas empiris, digunakan Model Rasch untuk melihat validitas butir masing-masing instrumen. Uji validitas ini dilakukan dengan bantuan program QUEST. Dalam program QUEST ditetapkan bahwa suatu item menjadi tidak fit menurut Model Rasch bila besarnya INFIT $t$ memiliki nilai $<-2,0$ atau $>+2,0$.

Berdasarkan hasil pengujian validitas butir instrumen lembar observasi kemampuan guru merencanakan pembelajaran Fisika menunjukkan bahwa dari 23 butir instrumen yang telah diuji terdapat 1 butir yang tidak valid yaitu butir nomor 20. Pada hasil pengujian validitas butir instrumen lembar observasi kemampuan guru melaksanakan pembelajaran menunjukkan bahwa dari 29 butir instrumen yang telah diuji terdapat 2 butir yang tidak valid yaitu butir nomor 11 dan nomor 25. Sehingga butir yang tidak valid tidak digunakan dalam perhitungan analisis data.

Program QUEST juga menyajikan hasil reliabilitas tes menurut teori tes klasik, yakni berupa indeks konsistensi internal (internal consistency). Nilai internal consistency untuk analisis data politomus merupakan indeks alpha Cronbach (Adam \& Khoo (1996) dalam Subali \& Suyata (2011, p. 11). Berdasarkan hasil analisis dengan program QUEST diperoleh nilai internal consistency lembar observasi kemampuan guru merencanakan dan melaksanakan pembelajaran masing-masing sebesar 0,93 dan 0,89 .

\section{Teknik Analisis Data}

Data yang akan dianalisis dalam penelitian ini meliputi kemampuan guru merencanakan dan melaksanakan pembelajaran Fisika. Data yang diperoleh berupa data kuantitatif. Oleh karena itu, analisis data yang digunakan adalah deskriptif kuantitatif. Analisis kuantitatif dilakukan dengan menentukan kategorisasi kemampuan guru merencanakan dan melaksanakan pembelajaran Fisika dan memberikan jawaban atas pertanyaan penelitian. Langkah yang perlu dilakukan adalah menentukan dahulu mean idea (Mi), simpangan baku ideal (SBi) serta skor tertinggi ideal dan skor terendah ideal masingmasing variabel sebagai kriteria. Untuk mendeskripsikan kemampuan guru dalam merencanakan dan melaksanakan pembelajaran Fisika digunakan skor rerata ideal sebagai norma perbandingan dengan lima kriteria seperti terlihat pada Tabel 1.

Tabel 1. Kriteria Penilaian Ideal

\begin{tabular}{ccc}
\hline No. & Rentang Skor & Kriteria \\
\hline 1. & $\mathrm{X}>\mathrm{Xi}+1,8 \mathrm{SBi}$ & Sangat Baik \\
& & \\
2. & $\mathrm{Xi}+0,6 \mathrm{SBi}<\mathrm{X} \leq \mathrm{Xi}+1,8 \mathrm{SBi}$ & Baik \\
3. & $\mathrm{Xi}-0,6 \mathrm{SBi}<\mathrm{X} \leq \mathrm{Xi}+0,6 \mathrm{SBi}$ & Cukup Baik \\
4. & $\mathrm{Xi}-1,8 \mathrm{SBi}<\mathrm{X} \leq \mathrm{Xi}-0,6 \mathrm{SBi}$ & Kurang Baik \\
5. & $\mathrm{X} \leq \mathrm{Xi}-1,8 \mathrm{SBi}$ & Sangat \\
& & Kurang Baik \\
\hline
\end{tabular}

Dari langkah-langkah tersebut, diperoleh kriteria penilaian kemampuan guru dalam merencanakan dan melaksanakan pembelajaran Fisika seperti terlihat pada Tabel 2.

Tabel 2. Kriteria Penilaian Data Observasi Kemampuan Guru Merencanakan dan Melaksanakan Pembelajaran Fisika

\begin{tabular}{ccc}
\hline No. & Rentang Skor & Kriteria \\
\hline 1. & $\mathrm{X}>85$ & Sangat Baik \\
2. & $70<\mathrm{X} \leq 85$ & Baik \\
3. & $55<\mathrm{X} \leq 70$ & Cukup Baik \\
4. & $40<\mathrm{X} \leq 55$ & Kurang Baik \\
5. & $\mathrm{X} \leq 40$ & Sangat Kurang Baik \\
\hline
\end{tabular}




\section{HASIL DAN PEMBAHASAN}

Berdasarkan hasil observasi diperoleh data kemampuan guru merencanakan dan melaksanakan pembelajaran. Deskripsi kemampuan guru dalam merencanakan dan melaksanakan pembelajaran ditunjukkan pada Tabel 3 dan Tabel 4.

Persentase sub aspek yang dinilai pada kemampuan guru merencanakan pembelajaran memiliki nilai yang bervariasi. Kemampuan guru dalam merencanakan pembelajaran memiliki persentase $82,99 \%$ dengan kategori baik. Pada sub aspek identitas RPP yang dibuat oleh guru sudah lengkap yang meliputi identitas sekolah atau tingkat satuan pendidikan, mata pelajaran, kelas/semester, dan alokasi waktu yang menggambarkan sasaran RPP untuk dilaksanakan. Pada sub aspek melengkapi identitas RPP ini masuk kategori sangat baik dengan persentase $95,45 \%$.

Tabel 3. Deskripsi Kemampuan Guru Merencanakan Pembelajaran

\begin{tabular}{llc}
\hline No & \multicolumn{1}{c}{ Sub Aspek } & $\begin{array}{c}\text { Persentase } \\
(\mathbf{\%})\end{array}$ \\
\hline A. & $\begin{array}{l}\text { Melengkapi identitas RPP } \\
\text { B. }\end{array}$ & $\begin{array}{l}\text { Memetakan kompetensi dasar } \\
\text { dan indikator }\end{array}$ \\
C. & $\begin{array}{l}\text { Mengidentifikasi, } \\
\text { mengembangkan dan }\end{array}$ \\
& $\begin{array}{l}\text { mengorganisasikan materi, media } \\
\text { pembelajaran dan sumber belajar }\end{array}$ \\
D. & \\
& $\begin{array}{l}\text { Menyusun skenario kegiatan } \\
\text { pembelajarn }\end{array}$ & 75,00 \\
E. & $\begin{array}{l}\text { Merencanakan prosedur, jenis } \\
\text { dan menyiapkan alat penilaian }\end{array}$ \\
F. & $\begin{array}{l}\text { Tampilan dokumen RPP } \\
\text { Rata-rata aspek perencanaan }\end{array}$ \\
\hline
\end{tabular}

Selain melengkapi identitas RPP, guru memetakan kompetensi dasar dan indikator. Indikator sudah dirumuskan sesuai dengan kompetensi dasar yang sudah ditentukan pada Kurikulum 2013. Kompetensi dasar sikap spiritual, sikap sosial, pengetahuan, dan keterampilan sudah dimuat secara utuh, namun penjabaran indikator pada keterampilan masih belum ada yang sesuai, yaitu kata kerja operasional yang digunakan belum mencapai yang tercantum pada kompetensi dasar. Pada sub aspek memetakan kompetensi dasar dan indikator ini masuk pada kategori baik dengan persentase $72,73 \%$.

Dalam mengidentifikasi, mengembangkan, dan mengorganisasikan materi, media pembelajaran dan sumber belajar sudah baik.
Guru mengidentifikasi dan mengembangkan materi pembelajaran, guru memilih media pembelajaran yang sesuai dengan karakteristik materi yang diajarkan, guru mengembangkan media pembelajaran yaitu menggunakan lebih dari satu media, guru memilih sumber belajar dengan baik dan tidak hanya bergantung pada satu buku atau sumber lainnya, namun pada bahan ajar, semua guru belum melakukan penyusunan dan pengembangan bahan ajar sesuai dengan potensi peserta didik dan perkembangan ilmu dan teknologi yang berhubungan dengan materi tersebut. Guru hanya mencantumkan nama materi pada RPP. Pada sub aspek mengidentifikasi, mengembangkan, dan mengorganisasikan materi, media pembelajaran dan sumber belajar masuk pada kategori baik dengan persentase $85,00 \%$.

Kegiatan pembelajaran yang disusun menurut Kurikulum 2013 seharusnya dilaksanakan berbasis aktivitas dengan mengutamakan keaktifan peserta didik dan kemandirian peserta didik, serta sesuai dengan perkembangan peserta didik. Oleh karena itu, untuk mencapai kegiatan pembelajaran yang diharapkan sebaiknya guru menyusun skenario kegiatan pembelajaran dengan baik, namun guru belum menentukan model pembelajaran yang ada pada Kurikulum 2013 (PjBL, PBL, dan Discovery Learning).

Pada langkah-langkah pembelajaran, guru menyusun dan merancang tahap-tahap pembelajaran yang direncanakan guru sejak awal hingga akhir pembelajaran yaitu menampilkan kegiatan pendahuluan, inti, dan kegiatan penutup, dilengkapi dengan pembagian waktu untuk setiap kegiatan. Guru juga telah menyusun langkah-langkah pembelajaran yang sesuai dengan pendekatan saintifik yang terdiri dari kegiatan mengamati, menanya, mengumpulkan informasi, mengasosiasi, dan mengkomunikasikan. Setiap langkah kegiatan sudah dirancang secara runtut. Namun, guru tidak merancang sintak kegiatan pembelajaran model pembelajaran yang ditentukan pada Kurikulum 2013. Pada kegiatan pendahuluan, kebanyakan guru merancang mempersiapkan peserta didik seperti mengecek kehadiran, kemudian menyampaikan kompetensi yang akan dicapai, garis besar materi dan kegiatan yang dilakukan, serta merencanakan pemberian motivasi. Namun, belum ada guru yang merencanakan untuk menyampaikan lingkup dan teknik penilaian yang akan dilakukan. Pada kegiatan penutup, guru merencanakan membuat rangkuman/simpulan pelajaran, umpan balik, dan menyampai- 
kan rencana pembelajaran berikutnya. Namun jarang guru merencanakan untuk melakukan refleksi atau tindak lanjut seperti pemberian remedial dan tugas pengayaan. Dalam merancang langkah-langkah pembelajaran juga diperlukan persiapan pertanyaan/perintah yang akan disampakan kepada peserta didik pada pembelajaran, pertanyaan/perintah yang direncanakan guru kebanyakan merupakan pertanyaan analisis dan/atau sintesis. Pada sub aspek menyusun skenario pembelajaran masuk kategori baik dengan persentase $75,00 \%$.

Penilaian hasil belajar oleh guru dilakukan untuk memantau proses, kemajuan belajar, dan perbaikan hasil belajar peserta didik secara berkesinambungan. Kurikulum 2013 mempersyaratkan penggunaan penilaian autentik yang mencakup kompetensi sikap (spiritual dan sosial), pengetahuan, dan keterampilan. Pada sub aspek merencanakan prosedur, jenis dan menyiapkan alat penilaian masuk pada kategori baik dengan persentase $82,27 \%$, namun dokumen penilaian kompetensi sikap belum lengkap dan masih jarang guru yang menyiapkan pembelajaran remedial dan pengayaan.

Tampilan dokumen RPP secara umum sudah sangat baik, tulisan dapat dibaca dengan mudah, tampilan bersih dan lumayan menarik, namun ada beberapa tulisan yang kurang konsisten atau belum sesuai EYD, seperti bahasa asing yang tidak dicetak miring, namun secara umum struktur kaliman yang digunakan kalimat baku. Sub aspek dokumen RPP ini masuk kategori sangat baik dengan persentase $87,50 \%$.

Tabel 4. Deskripsi Kemampuan Guru Melaksanakan Pembelajaran

\begin{tabular}{clc}
\hline No. & \multicolumn{1}{c}{ Sub Aspek } & $\begin{array}{c}\text { Persentase } \\
(\mathbf{\%})\end{array}$ \\
\hline A. & $\begin{array}{l}\text { Mengelola ruang dan fasilitas } \\
\text { pembelajaran }\end{array}$ & 79,92 \\
B. & $\begin{array}{l}\text { Melaksanakan kegiatan } \\
\text { pembelajaran }\end{array}$ & 62,41 \\
C. & Mengelola interaksi kelas & 92,05 \\
D. & $\begin{array}{l}\text { Bersikap terbuka dan luwes serta } \\
\text { membantu mengembangkan }\end{array}$ & 76,52 \\
& $\begin{array}{l}\text { sikap positif peserta didik } \\
\text { terhadap belajar }\end{array}$ \\
E. & $\begin{array}{l}\text { Mendemonstrasikan kemampuan } \\
\text { khusus dalam pembelajaran mata }\end{array}$ \\
& $\begin{array}{l}\text { pelajaran } \\
\text { F. }\end{array}$ \\
& $\begin{array}{l}\text { Melaksanakan penilaian dalam } \\
\text { pembelajaran saintifik }\end{array}$ \\
G. & $\begin{array}{l}\text { Kesan umum kinerja guru } \\
\text { Rata-rata aspek perencanaan }\end{array}$ \\
\hline
\end{tabular}

Persentase sub-aspek yang dinilai pada kemampuan guru melaksanakan pembelajaran memiliki nilai yang bervariasi seperti yang ditunjukkan pada Tabel 4. Kemampuan guru melaksanakan pembelajaran memiliki persentase $73,88 \%$ dengan kategori baik.

Pada sub-aspek mengelola ruang dan fasilitas pembelajaran berlangsung baik dan memiliki kategori baik dengan persentase $79,92 \%$, sebelum memulai pembelajaran guru melaksanakan tugas harian kelas seperti mengecek kehadiran peserta didik, memeriksa ketersediaan alat tulis, kebersihan dan kerapian papan tulis, serta memeriksa kesiapan peserta didik mengikuti pelajaran. Dalam menyiapkan sumber belajar yang dimanfaatkan dalam kelas, guru menggunakan lebih dari satu sumber.

Pada sub aspek melaksanakan kegiatan pembelajaran masuk kategori cukup baik dengan persentase $62,41 \%$. Sub aspek ini terdiri dari beberapa indikator yang diamati. Pada saat memulai kegiatan pembelajaran, rata-rata guru memotivasi peserta didik dengan mengajukan pertanyaan yang menantang atau menceritakan peristiwa yang kontekstual dan memberikan apersepsi atau mengaitkan materi pembelajaran dengan pengalaman peserta didik, namun jarang guru yang menyampaikan kompetensi pembelajaran yang harus dicapai dan manfaatnya dalam kehidupan sehari-hari serta menggambarkan garis besar materi dan kegiatan yang akan dilaksanakan, padahal kegiatan ini perlu dilakukan guru untuk menyiapkan fisik dan mental peserta didik, serta memberikan gambaran pada peserta didik kompetensi apa yang harus mereka capai agar pembelajaran bisa terlaksana secara optimal. Indikator kemampuan guru memulai pembelajaran masuk kategori baik dengan persentase $75,00 \%$.

Dalam kemampuan menguasai materi pelajaran, guru selalu menyesuaikan materi dengan kompetensi yang akan dicapai, mengaitkan materi dengan pengetahuan lain, perkembangan iptek, maupun kehidupan nyata, serta selalu menyajikan materi secara sistematis, yaitu dari mudah ke sulit, sehingga indikator kemampuan guru penguasaan materi pelajaran masuk kategori sangat baik dengan persentase $87,50 \%$.

Pada Kurikulum 2013, pendekatan pembelajaran sebagaimana yang sudah tertera pada Permendikbud Nomor 103 Tahun 2014 Tentang Pembelajaran pada Pendidikan Dasar dan Pendidikan Menengah adalah menggunakan pendekatan saintifik/pendekatan berbasis proses keilmuan. Pada pembahasan sebelumnya tentang 
kemampuan guru merencanakan pembelajaran, guru sudah menyusun langkah-langkah pembelajaran yang sesuai dengan pendekatan saintifik, namun pada saat pelaksanaannya, sedikit sekali guru yang menggunakan pendekatan saintifik seperti yang tertera pada RPP yang dirancang guru.

Secara garis besar guru menggunakan metode ceramah dan powerpoint sebagai media pembelajaran, sehingga pembelajaran yang dilaksanakan tidak interaktif dan inspiratif, kurang memotivasi peserta didik untuk berpartisipasi aktif, dan peserta didik menjadi kurang mandiri. Pada kegiatan mengamati, masuk kategori kurang baik dengan persentase $52,27 \%$, secara umum guru menyajikan perangkat pembelajaran berupa media seperti video, gambar, miniatur, tayangan, atau objek secara nyata, setelah itu guru mendorong peserta didik untuk melakukan pengamatan. Padahal selain kegiatan tersebut, pada saat mengamati peserta didik juga mendeskripsikan/menuliskan hasil pengamatannya, kemudian mengemukakan pendapatnya di depan kelas mengenai objek yang sedang diamati tetapi hal ini jarang dilakukan guru, pada saat melakukan pun hanya satu kelompok yang disuruh maju ke depan kelas karena takut waktunya tidak cukup. Pada kegiatan menanya, masuk kategori kurang baik dengan persentase $53,41 \%$, rata-rata pada kegiatan ini yang bertanya adalah guru yaitu dengan mengarahkan peserta didik dengan pertanyaan-pertanyaan agar peserta didik memahami materi agar kompetensi tercapai. Sebaiknya pada pembelajaran, peserta didik dapat mengajukan pertanyaan tentang informasiinformasi yang tidak dipahami dari apa yang diamatinya, sehingga pada kesempatan bertanya ini peserta didik dapat mengembangkan kompetensi rasa ingin tahunya dan proses pembelajaran memiliki kebermaknaan yang tinggi. Guru harus mampu menginspirasi peserta didik untuk mau dan mampu menanya, dalam hal ini, peserta didik tidak mudah menanya apabila tidak dihadapkan dengan media yang menarik. Pada kegiatan mengumpulkan informasi masuk kategori kurang baik dengan persentase $46,59 \%$, beberapa guru ada yang sama sekali tidak melaksanakan kegiatan ini, dan beberapa guru lain hanya membuka kesempatan secara luas kepada peserta didik untuk mencari berbagai informasi melalui berbagai sumber seperti buku, internet, atau praktikum. Namun jarang sekali guru membagi peserta didik menjadi beberapa kelompok untuk memudahkan pengumpulan informasi, hal ini dikarenakan hanya beberapa guru yang melaksanakan kegiatan pendekatan saintifik dengan membagi kelompok. Pada kegiatan mengasosiasikan masuk kategori kurang baik dengan persentase $47,73 \%$, pada bagian ini peserta didik mengolah/menyusun informasi yang telah mereka kumpulkan baik terbatas dari hasil kegiatan mengumpulkan/eksperimen maupun hasil dari kegiatan mengamati dan kegiatan mengumpulkan informasi yang telah diarahkan oleh guru. Pada kegiatan mengkomunikasikan masuk kategori kurang baik dengan persentase $45,45 \%$.

Masih jarang sekali guru menerapkan model-model pembelajaran yang ditentukan pada Kurikulum 2013 seperti PBL, PjBL, dan discovery learning. Kemampuan guru menggunakan model pembelajaran yang sesuai Kurikulum 2013 masuk kategori kurang baik dengan persentase $42,05 \%$, hasil observasi menunjukkan bahwa hanya dua atau tiga orang guru saja yang menggunakan model pembelajaran yang sesuai Kurikulum 2013 dengan model yang dominan adalah problem based learning. Pada saat guru menerapkan model problem based learning di kelas, langkahlangkah sudah sesuai dengan yang direncanakan pada RPP, guru menginformasikan tujuan pembelajaran, memotivasi peserta didik, mengorganisasikan peserta didik untuk belajar, guru membantu penyelidikan pada saat peserta didik melakukan diskusi kelompok, guru membantu peserta didik merencanakan dan menyiapkan hasil penyelidikannya kemudian mempresentasikan hasil masing-masing kelompok, serta guru membantu dan membimbing peserta didik melakukan refleksi atas apa yang telah diselidiki. Pada saat PBL berlangsung, guru berperan sebagai penyaji, penanya, pembimbing, dan negosiator, peran guru sudah dilakukan dengan baik. Namun guru mengalami kendala pada saat mengorganisasikan peserta didik, hal ini dikarenakan pembagian kelompok dengan anggota yang sedikit sehingga jumlah kelompok menjadi banyak. Sistem sosial pada saat PBL berlangsung baik, peserta didik aktif dalam pembelajaran, namun masih kurang mengemukakan pendapatnya. Sistem pendukung yang digunakan guru saat menerapkan PBL yaitu peralatan demonstrasi, bahan ajar, dan lembar kerja peserta didik.

Kemampuan guru menggunakan media pembelajaran, memanfaatkan media pembelajaran, dan menutup pembelajaran masuk kategori cukup baik dengan persentase masing-masing 
adalah 64,77\%, 65,91\%, dan 69,32\%. Hasil observasi menunjukkan bahwa kebanyakan guru menggunakan satu media dan sesuai dengan materi serta kebutuhan peseta didik. Dalam hal ini guru menggunakan media LCD dengan menampilkan video atau slide/power point saja. Guru sudah menunjukkan kemampuan dalam penggunaan sumber belajar dan media pembelajaran, namun media yang ditampilkan belum menghasilkan pesan yang menarik, serta jarang guru yang melibatkan peserta didik dalam pemanfaatan media pembelajaran. Pada kegiatan menutup pembelajaran, secara umum guru hanya melaksanakan tindak lanjut dengan memberikan arahan kegiatan berikutnya, jarang sekali guru melakukan refleksi atau membuat rangkuman serta memberi tes lisan ataupun tulisan. Selama kegiatan pembelajaran berlangsung, pembelajaran tidak dilaksanakan sesuai perincian waktu yang ditentukan, namun guru sudah memulai dan meakhiri pembelajaran tepat waktu.

Pada sub-aspek kemampuan guru mengelola interaksi kelas masuk kategori sangat baik dengan persentase $92,05 \%$. Kemampuan guru dalam berkomunikasi dengan peserta didik sudah sangat baik, pembicaraan guru lancar dan dapat dimengerti oleh peserta didik, materi yang ditulis di papan tulis atau media lain dapat dibaca dengan jelas, serta isyarat dan gerakan badan guru tepat. Selama berinteraksi di dalam kelas, guru memelihara keterlibatan peserta didik dengan baik, seperti membantu peserta didik mengingat kembali pengalaman atau pengetahuan yang sudah diperolehnya, mendorong peserta didik yang pasif untuk berpartisipasi, serta mengajukan pertanyaan-pertanyaan yang mampu menggali reaksi peserta didik. Namun hanya beberapa guru saja yang menanggapi secara positif peserta didik yang berpartisipasi.

Pada sub-aspek bersikap terbuka dan luwes serta membantu mengembangkan sikap positif peserta didik terhadap belajar masuk kategori baik dengan persentase $76,52 \%$, setiap guru menampilkan sikap bersahabat kepada peserta didik dan menghargai setiap adanya perbedaan pendapat. Guru mendekati peserta didik dan memperhatikan hal yang dikerjakan peserta didik serta memberikan bantuan kepada peserta didik yang membutuhkan. Namun masih jarang guru yang memberi pujian kepada peserta didik yang berhasil atau memberi semangat kepada peserta didik yang belum berhasil, jarang guru yang mendorong peserta didik agar berani mengemukakan pendapat sendiri. Selam observasi, guru telah menunjukkan kegairahan mengajar dengan baik.

Pada sub aspek mendemonstrasikan kemampuan khusus dalam pembelajaran mata pelajaran Fisika masuk kategori cukup baik dengan persentase $62,50 \%$. Ketika guru menyampaikan materi pembelajaran Fisika, hendaknya guru tidak hanya memberi contoh penerapan konsep Fisika dalam kehidupan sehari-hari, namun guru juga mendorong peserta didik untuk memberi contoh penerapan konsep tersebut misal dua atau lebih peserta didik. Namun kenyataannya hanya guru yang memberi contoh penerapan konsep, padahal pemahaman konsep Fisika peserta didik menjadi lebih baik apabila konsep itu diterapkan dalam kehidupan sehari-hari. Selain itu, materi pembelajaran harus dikuasai oleh guru. Materi pokok dalam Fisika dapat berupa konsep, prinsip, teori, dan hukum. Hasil observasi menunjukkan bahwa penguasaan materi Fisika guru sudah sangat baik.

Pada sub aspek melaksanakan penilaian dalam pembelajaran saintifik masuk kategori cukup baik dengan persentase 68,18\%. Pada penilaian proses atau keterampilan, ada guru yang hanya mengajukan pertanyaan atau memberikan tugas kepada peserta didik, ada juga yang menilai penguasaan peserta didik melalui kinerja yang ditunjukkan peserta didik. Penilaian proses atau keterampilan ini dapat dilakukan melalui observasi saat peserta didik bekerja kelompok, bekerja individu, berdiskusi, maupun saat presentasi dengan menggunakan lembar observasi kerja. Pada penilaian produk, hasil observasi menunjukkan bahwa kebanyakan guru tidak memberikan tes tertulis/penugasan di akhir pembelajaran. Pada penilaian sikap, guru hanya melihat sikap peserta didik tetapi tidak langsung dicatat. Penilaian sikap dilakukan melalui observasi saat peserta didik bekerja kelompok, bekerja individu, berdiskusi, maupun saat presentasi dengan menggunakan lembar observasi sikap.

Pada sub aspek kesan umum kinerja guru masuk kategori baik dengan persentase $75,57 \%$. Dalam mengelola pembelajaran cukup baik, guru cukup berhasil dalam mengendalikan pembelajaran sehingga pembelajaran berlangsung lancar. Kemampuan guru dalam menggunakan bahasa Indonesia sudah baik dengan ucapan yang jelas dan mudah dimengerti. Hasil observasi juga menunjukkan bahwa penampilan guru secara keseluruhan dalam mengelola 
pembelajaran (fisik, gaya mengajar, dan ketegasan) sudah sangat baik.

Berdasarkan hasil wawancara tidak berstruktur yang dilakukan peneliti ketika bertatap muka dengan guru Fisika, terdapat beberapa kendala dalam menerapkan model-model pembelajaran yang ditentukan pada Kurikulum 2013. Seperti yang telah diketahui bahwa model pembelajaran yang ditentukan pada Kurikulum 2013 ada tiga, yaitu Problem Based Learning $(P B L)$, Project Based Learning (PjBL), dan Discovery Learning. Secara umum, kendala yang dihadapi guru terdapat pada pelaksanaan pembelajaran terutama dalam menerapkan model-model yang ditentukan pada Kurikulum 2013. Guru tidak bisa menerapkan model-model pembelajaran tersebut pada setiap materi dikarenakan alokasi waktu yang tidak cukup, khususnya untuk kelas XII. Pada satu semester, guru hanya beberapa kali menggunakan modelmodel pembelajaran tersebut dan menyesuaikan dengan materi pembelajaran. Untuk mengantisipasinya, guru menggunakan model pembelajaran yang bervariasi, tidak hanya model pembelajaran Kurikulum 2013, hal ini dilakukan agar semua materi tersampaikan.

Kenyataan di lapangan ketika observasi dilakukan, hanya beberapa guru yang menerapkan model-model pembelajaran yang ditentukan pada Kurikulum 2013, model pembelajaran yang diterapkan yaitu problem based learning. Berdasarkan observasi, kendala yang dihadapi guru pada saat menerapkan model problem based learning (PBL) di kelas adalah dalam mengorganisasi atau skenario PBL itu sendiri. Peserta didik masih memerlukan bimbingan lebih dari guru, terutama dalam merumuskan masalah dan pemecahannya.

Kendala yang kedua yaitu kendala mengenai penilaian, beberapa guru memang merencanakan penilaian autentik yang terdiri dari penilaian proses, produk, dan sikap, dokumen sudah disiapkan, namun pada penilaian sikap tidak bisa menilai setiap peserta didik pada saat di kelas, penilaian dilakukan secara merata dan melihat yang kelihatan menonjol di kelas. Untuk penilaian proses, guru dapat melakukan penilaian proses selama pembelajaran. Selain kendala pada saat pelaksanaan, terdapat juga kendala pada saat guru merencanakan pembelajaran. Berubahnya peraturan tentang pembuatan RPP, menyebabkan guru harus mengubah format RPP yang telah dibuat guru sebelumnya. Ada beberapa perbedaan antara RPP berdasarkan Permendikbud Nomor 81A Tahun 2013 dengan RPP berdasarkan Permendikbud Nomor 103 Tahun 2014. Dari perubahan tersebut sehingga menimbulkan dampak positif maupun nampak negatif. Pada dampak negatif yang juga menjadi kendala guru, yaitu dengan adanya perubahan format RPP Kurikulum 2013 ini mengakibatkan guru harus menyusun ulang RPP, perlu adanya lagi biaya untuk mencetak RPP, perlu waktu dan tenaga yang lebih lagi, karena guru mata pelajaran harus melakukan MGMP.

Berubahnya peraturan tentang perencanaan pembelajaran pada Kurikulum 2013 tidak hanya pada perubahan format RPP, selain itu juga berubah-ubahnya skala penilaian pembelajaran, yang sebelumnya berbentuk angka dengan rentang $0-10$, kemudian berubah menjadi bentuk huruf, kemudian berubah lagi menjadi bentuk angka dengan rentang 0-100.

\section{SIMPULAN}

Berdasarkan hasil penelitian tentang kemampuan guru Fisika SMA Negeri di Kabupaten Sleman dalam menerapkan model-model pembelajaran yang ditentukan pada Kurikulum 2013 serta kendala-kendala yang dihadapi dapat diperoleh kesimpulan (1) kemampuan guru Fisika SMA Negeri di Kabupaten Sleman dalam merencanakan pembelajaran dengan modelmodel pembelajaran yang ditentukan pada Kurikulum 2013 masuk kategori baik; (2) kemampuan guru Fisika SMA Negeri di Kabupaten Sleman dalam melaksanakan pembelajaran dengan model-model pembelajaran yang ditentukan pada Kurikulum 2013 masuk kategori baik; dan (3) kendala-kendala yang menjadi hambatan bagi guru Fisika SMA Negeri di Kabupaten Sleman dalam menerapkan modelmodel pembelajaran yang ditentukan pada Kurikulum 2013 yaitu perubahan format RPP, alokasi waktu dan tahapan dalam mengorganisasi dalam melaksanakan model pembelajaran Kurikulum 2013, dan melaksanakan penilaian kompetensi sikap.

\section{DAFTAR PUSTAKA}

Cullen, C. L. (2011). The education of JapaneseAmericans, 1942-1946: The fate of democratic curriculum reform. American Educational History Journal, 38(1/2), 197.

Hasriani, A., \& Arty, I. S. (2015). Kontribusi motivasi, penguasaan informasi dan persepsi mahasiswa pendidikan kimia terhadap kesiapan implementasi 
Kurikulum 2013. Jurnal Inovasi Pendidikan IPA, I(2), 115. https://doi.org/10.21831/jipi.vli2.7495

Hussain, A., Dogar, A. H., Azeem, M., \& Shakoor, A. (2011). Evaluation of curriculum development process. International Journal of Humanities and Social Science, 1(14), 263-271. Retrieved from http://www.ijhssnet.com/journals/Vol_1_ No_14_October_2011/34.pdf

Kurniasih, I., \& Sani, B. (2014). Sukses mengimplementasikan Kurikulum 2013. Jakarta: Kata Pena.

Mundry, S., \& Loucks-Horsley, S. (1999). Designing professional development for science and mathematics teacher: Decision points and dilemmas. NISE Brief, 3(1), 1-8. Retrieved from http://archive.wceruw.org/nise/Publicatio ns/Briefs/Vol_3_No_1/Vol.3,No.1.pdf

Nadeem, M., Rana, M. S., Lone, A. H., Maqbool, S., Naz, K., \& Ali, A. (2011). Teacher's competencies and factors affecting the performance of female teachers in Bahawalpur (Southern Punjab)

Pakistan. International Journal of Business and Social Science, 2(19), 217222. Retrieved from http://www.ijbssnet.com/journal/index/74 1:vol-2-no-19-si-october-
2011 abstract $27 \&$ catid=19:hidden

Rezeki, U. S., \& Setiawan, D. (2015). Analisis kemampuan pedagogik guru sekolah dasar terhadap Kurikulum 2013 di Kecamatan Medan Area. Program Studi Pendidikan Dasar Program Pascasarjana Universitas Negeri Medan, 2(17), 302317.

Rohani, A. (2004). Pengelolaan pengajaran. Jakarta: PT. Rineka Cipta.

Rusman, R. (2010). Model-model pembelajaran mengembangkan profesionalisme guru. Jakarta: PT. RajaGrafindo Persada.

Subali, B., \& Suyata, P. (2011). Panduan analisis data pengukuran pendidikan untuk memperoleh bukti empirik kesahihan menggunakan program Quest. Yogyakarta: Lembaga Penelitian dan Pengabdian pada Masyarakat UNY.

Suparlan, S. (2008). Menjadi guru efektif. Yogyakarta: Hikayat Publishing.

Uno, H. B. (2007). Profesi kependidikan: problema, solusi, dan reformasi pendidikan di Indonesia. Jakarta: Bumi Aksara.

Wiyani, N. A. (2013). Manajemen kelas: Teori dan aplikasi untuk menciptakan kelas yang kondusif. Yogyakarta: Yogyakarta: Ar-Ruzz Media. 